Tohoku J. Exper. Med., 1960, 72, 194-196

\title{
Concurrent Infection with Influenza A-prime and $B$ Viruses in the Same Individual
}

\author{
By \\ Tooru Nakao \\ From the Depariment of Pediatrics, Aomori Prefectural Central \\ Hospital ; Pediatrician-in-Chief : Dr.T. $N$ akao
}

(Received for publication, February 29, 1960)

An epidemic of influenza is usually the result of infection with either influenza A virus or influenza B virus. So a concurrent infection with both influenza $\mathbf{A}$ and $\mathbf{B}$ viruses in a single epidemic or in one and the same individual is a very rare incidence.

From the end of April to May, 1955, in Aomori and its neighborhood an epidemic of influenza was prevalent. In the pediatric ward of our Hospital, many patients were attacked with influenza during this time. Laboratory investigation revealed that this epidemic was caused mainly by influenza virus A, though there were scattered cases of influenza B and those of influenza Aprime.

In the present paper I shall report a concurrent infection with influenza A-prime and $B$ viruses in one and the same patient who was admitted to the pediatric ward of our Hospital with the diagnosis; a neurological complication of pertussis.

\section{REPORT OF CASE}

A girl, aged 4 years and 7 months, complained of coughs from about April 4, 1955. The coughs increased then in frequency and duration, and the whoop characteristic of pertussis began to be noticed and she was treated as a case of pertussis. Though the coughs were diminished in frequency and duration, now she began to complain of a disturbance of gait on about April 16, 1955. Fever was hardly noticed. She was admitted to our Hospital on April 19, 1955, with the diagnosis; a neurological complication of pertussis. On examination, she was moderately nourished and heart sounds were clear. Coarse rales were heard over the entire chest. The liver was palpable $2.5 \mathrm{~cm}$ on the right nipple line below the costal margin. The spleen was not palpable. Patellar reflex was absent. She could neither stand nor walk. Fever rose up to $39^{\circ} \mathrm{C}$ on the night of admission, but abated on April 30, 1955. In the meantime she had begun

$$
\text { 中尾亭 }
$$


to stand; it was about April 24, then she gradually came to be able to walk normally. However, fever rose up to $37.5^{\circ} \mathrm{C}$ on May 3, 1955, on May 4 up to $38.5^{\circ} \mathrm{C}$ and on May 5 up to $39.5^{\circ} \mathrm{C}$. She complained also of general malaise, headache, pain of limbs and waist, nasal obstruction and discharge, sneezing and epistaxis. The pharynx was reddened. Coughs became again intense. Fever abated on May 6, and the above-mentioned symptoms subsided. Though fever rose again up to $39.5^{\circ} \mathrm{C}$ on May 11, it abated on the next day. She was discharged with an improvement on May 24, 1955.

TABLE I. Hemagglutination-inhibition of Serum in $\mathrm{My}$ own Patient of Concurrent Infection with both Influenza A-prime and B Viruses

\begin{tabular}{|c|c|c|c|}
\hline Date & Intluenza $A$ & $\begin{array}{l}\text { Influenza } \\
\text { A-prime }\end{array}$ & Inthuenza $B$ \\
\hline May $\begin{array}{r}\frac{2}{13} \\
\mathbf{2 3}\end{array}$ & $\begin{array}{l}1,024 \\
1,024 \\
8,192\end{array}$ & $\begin{array}{r}128 \\
2,048 \\
1,021\end{array}$ & $\begin{array}{l}1,024 \\
8,192 \\
8,192\end{array}$ \\
\hline
\end{tabular}

Hemagglutination-inhibition test against influenza virus, as is given in Table I, showed a significant rise of antibody titer for influenza virus $A$-prime and $B$ on May 13, and on May 23 it showed a significant rise of antibody titer for influenza virus $\mathrm{A}$.

\section{COMMENT}

Lennette $e a^{1 /}$ gave evidences that both influenza $A$ and $B$ would occur at the same time in the same population, and even in one and the same individual in a given epidemic. Then followed several reports of a similiar observation by other authors. ${ }^{2-5)}$ My patient with signs and symptoms of respiratory tract affection accompanied by such manifestations as fever, headache, general malaise, pains of limbs and epistaxis from May 3 to May 5, was diagnosed clinically as a case of influenza. Hemagglutination-inhibition test of serum against influenza virus, performed 11 days later, showed 16 -fold rise of antibody titer for influenza virus $A$-prime and 8 -fold rise of antibody titer for influenza B. This serological result revealed that the respiratory tract disease of my own case from May 3 to May 5, was caused by both influenza virus A-prime and influenza B. Then, hemagglutination-inhibition test of serum performed 10 days later showed 8-fold rise of antibody titer for influenza virus A. This result would show that the attack of fever on May 11 was caused by influenza virus A.

\section{SUMMARY}

A case of concurrent infection with both influenza A-prime and B viruses was reported. The diagnosis was established by a significant coincident rise of 
antibody titers against both influenza A-prime and B virus. Moreover, she was attacked about one week later with influenza $A$ which was again confirmed by the hemagglutination-inhibition test then performed (Cf. Table I).

\section{References}

1) Lennette, Richard, Hirst \& Horsfall, Pub. Health Report, 1941, 56, 1777.

2) Hare, Hamilton \& Feasby, Canad. J. Pub. Health, 1943, 34, 453.

3) Commission on Acute Respiratory Disease, Am. J. Hyg., 1948, 48, 263.

4) Burnet, Stone \& Anderson, Lancet, 1946, 1, 807.

5) Kilbourne, Anderson \& Horsfall, J. Immunol, 1951, 67, 547. 